\title{
Contribution of the Therapeutic Education to the Reduction of the Viral Load with the People Living with HIV in Ivory Coast: Case of the General Hospital of Dabou
}

\author{
Epezagne N'Gouandi \\ University Alassane Ouattara Bouake /(fateac), Ivory Coast \\ Health Inspector, Psychiatrist, $\mathrm{PhD}$ sociology of organizations and governance \\ Epezagne Assamala Ingrid Ruth \\ Jiangsu university, China \\ telecom engineer, business development manager, Ph.D. management science and engineering \\ Agbroffi Diamoi Joachim \\ Senior lecturer sociology at the Alassane ouattara University of Bouaké Côte d'Ivoire \\ Kouassi Celestin \\ Senior lecturer geography at the Alassane ouattara University fateac Côte d'Ivoire
}

\begin{abstract}
Our research explores the adoption of the new approach for managing the insertion of HIV patients in the public hospital of Dabou, Ivory Coast. Our study of phenomenological type is in a context of the spread of the pandemic of the virus HIV forth 20th century (HIV/AIDS). With a big influence in sub-Saharan Africa, the complexity of the antiretroviral treatment, its side effects and especially risks of vial resistance. What justifies the use of therapeutic education throughout the whole process of recovery in France as well as in Ivory Coast? We used the public hospital of Dabou because of the strong group of people living with a high viral load of HIV in this town. Our aim is to show how therapeutic education can reduce the viral load among the people living with the HIV and treated at the public hospital of Dabou. Our sample is about 200 persons living with a high viral load which is over $5000 \mathrm{ml}$ of blood; we have been having one individual session and two group sessions with each of them. Our results confirm the usefulness of the therapeutic education in the care of people living with HIV for the reducing of their viral load.
\end{abstract}

Keywords: Therapeutic education, viral load, Detectable, Undetectable.

DOI: $10.7176 / \mathrm{JHMN} / 90-08$

Publication date:June $30^{\text {th }} 2021$

\section{Introduction}

\subsection{Context}

The Infection with the human immunodeficiency virus (HIV) has been one of the main development problems since the twentieth century and a major challenge to international health security(UNESCO 2006). At the end of 2013, UNAIDS counted 33.4 million people living with HIV worldwide (ONEC. 2013). With 20.8 million people infected, 2/3 of the world total, sub-Saharan Africa is still bearing an inordinate share of the weight of this pandemic (2016)(National Guide to Therapeutic Education for adults and children living with HIV). By the end of 2014, this trend had changed with 36.9 million people living with HIV worldwide, including 25.8 million in sub-Saharan Africa. In West Africa, Cote d'Ivoire is the country most affected by HIV with an estimated HIV prevalence of $4.7 \%$ in 2005 (sida 2005).

\subsection{Significance}

Despite the success of antiretroviral and the large number of people put on treatment: 15.8 million people in June 2015. The number of deaths linked to HIV infection remains significant with 1.2 million reported. (A. 2017) Furthermore, the side effects of certain antiretroviral (WWW.UNAC.org 2002) constitute obstacles to the implementation of treatment adherence. Achieving the undetectable viral load in people living with HIV, which is one of the pillars of achieving the 90.90 .90 targets for accelerating the national response to AIDS by 2020, requires a number of strategies (program 2016). Other methods of stopping the spread of the HIV pandemic by making the viral load disappear have appeared: therapeutic education (A. 2005) Indeed, the complexity of the treatments, their side effects and the risks linked to the emergence of viral resistance justified the setting up of educational programs for people living with HIV / AIDS,(C.) (Therapeutic education in HIV patients at the Nancy University Hospital). Similarly, its integrated patient-centered care programs help improve knowledge of the disease, knowledge of treatments, and management of the psychosocial aspect (Ogalama 2013). It is therefore a process that allows the 
patient to understand the basis for taking his ARV treatment (T.K 2009). By this process, the patient assimilates his illness better, he takes the medication correctly in order to reduce the viral load (HAS 2014), this is the main interest of education therapeutic. Faced with the scale of the epidemic in Côte d'Ivoire (sida 2005), the response of the Ivorian state quickly manifested itself through the creation of a ministry in charge of AIDS and of two programs with the taking of decrees and service notes in 2014. (Gandonou 2016)Despite everything, the latest estimates from the UNAIDS report in 2015 show that the prevalence of HIV infection in Côte d'Ivoire is $3.2 \%$ in the 15 to 59 age group and that in 2014, 9,304 new clients had access to HIV care and treatment services, bringing to 23,647 the number of adults and children put under treatment, (UNICEF 2010). Even with strategies targeting vulnerable populations, the pandemic continues to gain ground (Tiembré I. 2009). Thus, instead of therapeutic education as a strategy for the care of PLWHA in Côte d'Ivoire (ONUSUDA 2015).

\section{Problem statement}

The HIV / AIDS pandemic is a problem for humanity that does not yet seem to be resolved as it continues to devastate the human population. Indeed, at the end of December of the year 2014; the world had 36.9 million people living with HIV, including 25.8 million in sub-Saharan Africa (A.D. 2005), with 1.2 million deaths (E. 2010). Several strategies are being implemented to overcome this condition, such as the UNAIDS global strategy to end the AIDS epidemic by 2030. But also the "Test and Treat all" adopted by the Ivory Coast since February 1, 2017. It is in this context that the NGO ACONDA (Mutondon 2012)set up therapeutic education to allow the suppression of the viral load in people living with HIV. (ONUSIDA 2002)The observation of the implementation of therapeutic education in France in the care of People living with HIV at the Nantes and Angers University Hospital has allowed to obtain between $54.8 \%$ and $87.5 \%$ rate of adherence to ARV treatment in PLWHIV (Pohor Rubin). The research and training support center in Côte d'Ivoire has initiated a study: the introduction of therapeutic education in the follow-up of people living with antiretroviral drugs at the care and training center, Abidjan, Ivory Coast. (d'Haïti) Assessment after a year of activity from 01/2011 to 07/2012 (GOLI. CePReF, 2012). At Dabou general hospital there is a large population of people living with HIV (3,141 patients) and a very high viral load (1,658,000 copies / $\mathrm{ml}$ of blood), hence the introduction of therapeutic education in the course of care.

\subsection{Study setting}

The study took place in Dabou, capital of the region of the big city bridges located $27 \mathrm{~km}$ from Abidjan, the economic capital of the Ivory Coast.

Table 1 Demographic trends

\begin{tabular}{|l|l|l|l|l|}
\hline Year & 1975 & 1988 & 1998 & 2010 \\
\hline Population & 23.134 & 39.494 & 54.892 & 82.021 \\
\hline
\end{tabular}

\subsubsection{Site description}

We did our study at the general hospital of Dabou public health structure with several services including that of the care of people living with HIV created on February 27, 2007. At the beginning, the activities were shy but in recent years the service receives approximately 20 patients per day including 3 to 5 new cases. It is screened and started on antiretroviral therapy in accordance with the "Test and Treat All" approach. Before 2016, it was only doctors who prescribed antiretroviral; it is from 2016, with the training of nurses and midwives on the prescription of antiretroviral following the ministerial decree on the delegation of medical task for the prescription of first line antiretroviral that they are involved in this activity (Assata Pare Kabore 2014).

\subsubsection{Study type and period}

Our study is of phenomenological type of the population of patients infected with the HIV virus on antiretroviral treatment and with a very high viral load which started from February 13, 2017 to August 14, 2017, i.e. a duration of six months.

\subsection{Study population}

These are the patients who received after finding the high viral load, an individual therapeutic education session and then two group therapeutic education sessions.

\subsubsection{Target population}

The target population of our survey is all patients infected with the HIV virus on antiretroviral treatment for more than six months and followed at the Dabou general hospital with a high viral load more than $1000 \mathrm{copies} / \mathrm{ml}$ of blood.

\subsubsection{Source population}

The source population of our survey concerned patients followed at the Dabou general hospital for human immunodeficiency virus infection and whose viral load is high despite taking antiretroviral.

\subsubsection{Inclusion criteria}

Our survey concerned all patients on antiretroviral for six months and whose viral load is high. They are: All 
patients on antiretroviral with high viral load and having HIV 1. All HIV 1 patients on antiretroviral with viral load high and having attended the three therapeutic education sessions.

\subsubsection{Non-inclusion criteria}

HIV 2, HIV 1 and 2 (dual), People living with HIV under the age of 11, undetectable or suppressed viral load.

\subsection{Sampling procedures}

The population of HIV patients at Dabou General Hospital is 3,141 patients. Out of this total population we have a sample of 200 patients. Our sample was drawn from February 13, 2017 to August 14, 2017. The selection of patients was based on whether patients on ARVs for more than six months have a high viral load. Right now we are systematically offering them therapeutic education; thus they are integrated into our study. Regarding individual therapeutic education, we receive an average of 03 patients per day. As for group therapeutic education, we have groups of 10 people.

\subsubsection{Calculation of the sample size}

The size of our sample is related to the large number of patients with high viral load. Indeed, for 297 viral loads requested all returned high until the time of our study on February 13, 2017. Although all people living with HIV have a high viral load (more than 1000 copies / $\mathrm{ml}$ of blood), some loads viral values are very high at more than $1,658,000$ copies / $\mathrm{ml}$ of blood, or $6.21 \mathrm{log}$. Thus, we targeted our study towards patients with more than 5000 copies / $\mathrm{ml}$ of blood. Considering that our total population is 3141 patients and that we have 910 men and 2231 women; we proceeded by proportionality.

$\mathrm{H}=910 / 3141=29 \%, \mathrm{~F}=2231 / 3141=71 \%$

Given as sample:

$\mathrm{H}=58 \mathrm{~F}=142$

\begin{tabular}{|l|l|l|}
\hline Sexe & Nombre d'individu & Echantillon \\
\hline H & 910 & 58 \\
\hline F & 2231 & 142 \\
\hline Total & 3141 & 200 \\
\hline
\end{tabular}

Tableau 1 Sample details

Regarding the teenagers, we have a sample population of 30 patients as followed :

$\mathrm{H}=30 \times 29 / 100=9 \mathrm{~F}=30 \times 71 / 100=21$

\begin{tabular}{|l|l|l|}
\hline Gender & Number & Sample \\
\hline $\mathrm{H}$ & 910 & 9 \\
\hline $\mathrm{F}$ & 2231 & 21 \\
\hline Total & 3141 & 30 \\
\hline
\end{tabular}

Tableau 2 teenagers population

\subsubsection{Tools and mode of data collection}

Using a questionnaire, we collected the data during the individual therapeutic education sessions. We supplemented our information during group therapy education. This questionnaire is related to socio-professional characteristics, data related to HIV and data related to therapeutic education.

\subsubsection{Data collected}

The socio-professional characteristics which have served us as studies:

Age, sex, religion, level of education, professional activity, marital status, place of residence, kinship, patient's hobbies, addictive behaviors.

Data related to HIV:

This is the type of HIV, the CD4 count at the initiation then that at the time of the control, the viral load six months after taking the antiretroviral then that received three (03) months after the therapeutic education, it is also about the feeling at initiation and the feeling after the three sessions of therapeutic education.

Data related to therapeutic education:

The three therapeutic education sessions are the benchmarks for good therapeutic education. This is why it is necessary to ensure the number of individual therapeutic education carried out and the number of therapeutic group education accomplished. The verification of the educational diagnosis must be done through knowledge at the level of the cognitive dimension, the bio clinical dimension, the psych affective dimension, and the motivational dimension. Subsequently we looked at the influencing factors, to continue with the educational contract with the skill of self-care, the skill of adaptation and finally Self-efficacy. Through the information received, we evaluated the effectiveness of the tools used in therapeutic education. Indeed, the vitality of therapeutic education being in relation to the information received; but also and above all of the explanations provided by the educator, the instruments such as the True or False report, CD4 / CV, and especially the therapeutic funnel constitute a good lever to evaluate his reception. 


\subsubsection{Survey data collection process}

The investigation lasted six (06) months and spanned all working days of the week. Indeed, for individual therapeutic education the patients are received one after the other and we receive three (03) patients per day. Thus the 200 patients were seen for 67 working days. We have reserved Wednesday for group therapeutic education sessions that take place between 12 p.m. and 2 p.m. Also, the 200 patients who have a viral load greater than 5000 copies / $\mathrm{ml}$ of blood 06 months after taking ARVs were all received individually once, then they were seen in groups of 10 people twice over a period 40 days. In total, the activity of therapeutic education lasted 107 days, after which three months later we redid the viral load for control.

\subsubsection{Validation of data collection tools}

We presented our data collection instruments to our Research Director in order to approve the relevance of the formulation of the questionnaires and their importance in the subject of the research. It was after his approval and after correction of the remarks made by him that we started our work at the general hospital and with people

\subsubsection{Simulation test}

Before presenting our instrument to our Director for verification we did a simulation for two days (Monday January 30, 2017 to Tuesday January 31, 2017) with people living with HIV with high viral load from the Methodist hospital of Dabou in the goal to see their understanding of the questionnaires.

\subsubsection{The actual investigation}

All 200 patients benefited from the three interview times during our survey. Indeed, individual therapeutic education took place over 67 days with the passage of 200 patients. To do this, we used weekly from Monday to Friday (working). During our regular consultations, we allow time to receive our three patients each day of the week. It is at the level of group therapeutic education that we reserve Wednesdays between 12 noon and 2 p.m. to receive our patients. During the individual therapeutic education, we proceed to the collection of socio-professional characteristics, we continue with the data linked to HIV and finally we finish with the data linked to therapeutic education. We supplement the data related to therapeutic education during group therapeutic education, especially with the use of therapeutic education tools that allow patients to understand the evolution of drugs in their organism.

\section{RESULTS}

The active queue of people living with HIV on antiretroviral therapy at Dabou General Hospital during our study period gives us a total of 3,141 patients, including 297 with very high loads above 5,000 copies / ml of blood. With our sample of 200 people living with HIV including 58 men and 142 women; for 30 adolescents made up of 9 boys and 21 girls all with high viral load, we were able to do the three sessions of therapeutic education which are taken into account of our survey.

\begin{tabular}{|}
$\begin{array}{c}\text { ARV Patients at the public hospital of } \\
\text { Dabou (3141) }\end{array}$ \\
$\begin{array}{c}\text { ARV Patients with high viral load at } \\
\text { the public hospital of Dabou (297) }\end{array}$ \\
\hline $\begin{array}{c}\text { ARV Patients with viral load }>5000 \\
\text { copies /ml of blood (200) }\end{array}$ \\
$\begin{array}{c}\text { ARV Patients with viral load }>5000 \\
\text { copies who took part in } 3 \text { sessions of } \\
\text { ETP (200) }\end{array}$
\end{tabular}

Figure 1 Diagram giving the different stages of the selection of our patients (February - August 2017) N=200

\section{copies $>1000 \mathrm{copies} / \mathrm{ml}$ of blood (97)}

ARV Patients with viral load $>5000$ 


\subsection{Socio-professional data}

Table 4 Socio-professional characteristics of patients seen at Dabou general hospital from February 13, 2017 to August 14, 2017, $(N=200)$

\begin{tabular}{|c|c|}
\hline Variable & Number $\%$ \\
\hline Sex & \\
\hline Man............................. & $58(29)$ \\
\hline Women............................ & $142(71)$ \\
\hline Religion & \\
\hline Christian........................ & $67(33,5)$ \\
\hline Muslim............................. & $132(66)$ \\
\hline Neutral $\ldots \ldots \ldots \ldots \ldots \ldots \ldots \ldots \ldots \ldots \ldots$ & $1(0,5)$ \\
\hline Education level & \\
\hline Unschooled'..... & $89(44,5)$ \\
\hline 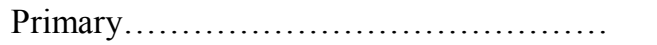 & $57(28,5)$ \\
\hline 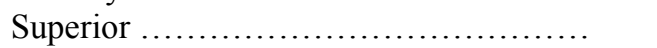 & $50(25)$ \\
\hline Koranic school..................... & $04(2)$ \\
\hline Professional activity & \\
\hline Unemployed........... & $80(40)$ \\
\hline Trader $\ldots \ldots \ldots \ldots \ldots \ldots \ldots \ldots \ldots$ & $102(51)$ \\
\hline 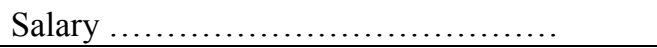 & $18(9)$ \\
\hline Marital status & \\
\hline Single........... & $122(61)$ \\
\hline Married'...$\ldots \ldots \ldots \ldots \ldots \ldots \ldots \ldots \ldots \ldots$ & $03(1,5)$ \\
\hline Concubine $\ldots \ldots \ldots \ldots \ldots \ldots \ldots \ldots \ldots \ldots \ldots \ldots \ldots \ldots$ & $70(35)$ \\
\hline Widower................................. & $05(2,5)$ \\
\hline Place of residence & \\
\hline Dabou .............. & $108(54)$ \\
\hline 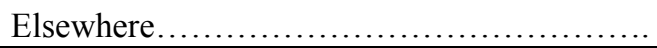 & $92(46)$ \\
\hline Cohabitation & \\
\hline Only.................................... & $100(50)$ \\
\hline 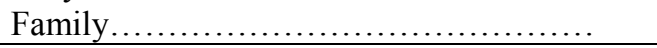 & $100(50)$ \\
\hline Addictive behaviors & \\
\hline Tobacco............................. & $50(25)$ \\
\hline Alcohol................................. & $30(15)$ \\
\hline Drug.................................. & $03(1,5)$ \\
\hline Neutral................................... & $117(58,5)$ \\
\hline
\end{tabular}

The gender distribution of people living with HIV with high viral load at Dabou General Hospital confirms data highlighting the feminization of the HIV pandemic. Indeed, for 200 people living with HIV with the high viral load seen at the Dabou general hospital between February and August 2017 there were 142 women or $71 \%$ and 58 men or $29 \%$ with a sex ratio of 0 , 41 . In terms of religion, 67 people living with HIV (33.5\%) were Christian, 132 people (66\%) were Muslim and only 1 person $(0.5 \%)$ was neutral or said to have no religion.

Regarding schooling, 57 patients or $28.5 \%$ of our study population had the primary level, 89 people or $44.5 \%$ were not educated, 50 people or $25 \%$ had the higher level only 04 people or $2 \%$ had done the Koranic school had noted that for professional activities, 80 patients or $40 \%$ of our study population had no activities, 102 people or $51 \%$ were traders and that 18 people or $9 \%$ were salaried '. In terms of marital status, we noted that 122 people living with HIV with high viral load at Dabou general hospital or $61 \%$ were single, 3 people or $1.5 \%$ were married, 70 patients or $35 \%$ lived in cohabitation and only 5 people or $2.5 \%$ were widows. As for the place of residence, we 108 patients from our study population lived in Dabou, that is 54\% while 92 people or $46 \%$ came from elsewhere; and that 100 of the people living with HIV in our sample lived with parents or $50 \%$ while the other 100 lived alone or $50 \%$. As for addictive behaviors, it should be noted that 30 people living with HIV with high viral load at the general hospital of Dabou consumed alcohol or $15 \%, 50$ people or $25 \%$ took tobacco, 3 people or $1,5 \%$ used the drug (Indian hemp), however 117 people or $58.5 \%$ did not take anything. 


\subsection{HIV-related data}

Table 5: Data related to HIV from February to August 2017

\begin{tabular}{|c|c|}
\hline Variables & Number\% \\
\hline $\begin{array}{l}\text { Type of HIV } \\
\text { HIV } 1 \ldots \ldots \ldots \ldots \ldots \ldots \ldots \ldots \ldots \ldots \ldots \ldots \ldots\end{array}$ & $200(100)$ \\
\hline $\begin{array}{l}\text { CD4 initiation rate } \\
<200 \mathrm{~mm} 3 \ldots \ldots \ldots \ldots \ldots \ldots \ldots \ldots \ldots \ldots \ldots \ldots \\
{[200-500 \mathrm{~mm} 3] \ldots \ldots \ldots \ldots \ldots \ldots \ldots \ldots \ldots \ldots}\end{array}$ & $\begin{array}{l}185(92,5) \\
15 \quad 7,5)\end{array}$ \\
\hline $\begin{array}{l}\text { Last } \mathrm{cd} 4 \\
>500 \mathrm{~mm} 3 \ldots \ldots \ldots \ldots \ldots \ldots \ldots \ldots \ldots \ldots\end{array}$ & $200(100)$ \\
\hline 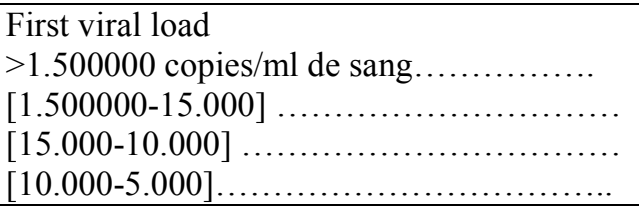 & $\begin{array}{l}1(0,5) \\
128(64) \\
50(25) \\
21(10,5)\end{array}$ \\
\hline $\begin{array}{l}\text { Last viral load } \\
<1000 \text { copies } / \mathrm{ml} \text { of blood } \ldots \ldots \ldots \ldots \ldots \ldots \ldots\end{array}$ & $200(100)$ \\
\hline 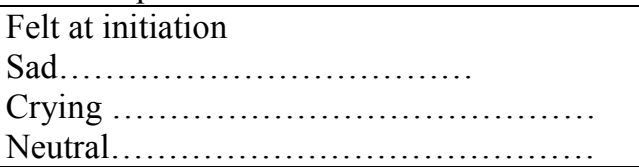 & $\begin{array}{l}149(74,5) \\
50(25) \\
1(0,5)\end{array}$ \\
\hline $\begin{array}{l}\text { Felt current } \\
\text { Good } \ldots \ldots \ldots \ldots \ldots \ldots \ldots \ldots \ldots \ldots \ldots \ldots \ldots\end{array}$ & $200(100)$ \\
\hline $\begin{array}{l}\text { Initiation of ARVs } \\
\text { Morning and evening } \ldots \ldots \ldots \ldots \ldots \ldots \ldots \ldots\end{array}$ & $200(100)$ \\
\hline $\begin{array}{l}\text { Taking current ARVs } \\
\text { Fixed time }(8 \text { p.m. }) \ldots \ldots \ldots \ldots \ldots \ldots \ldots \ldots \ldots \ldots\end{array}$ & $200(100)$ \\
\hline
\end{tabular}

All of our study population has HIV 1 or $100 \%$ of our patients. At the start of treatment, 185 people living with HIV or $92.5 \%$ had a cd4 below $200 \mathrm{~mm} 3$ and 15 people or $7.5 \%$ had cd4 between 200 and $500 \mathrm{~mm} 3$ of blood. After therapeutic education, all people living with HIV had cd4 greater than $500 \mathrm{~mm} 3$ of blood. A person living with HIV had a viral load greater than 1,500,000 copies / $\mathrm{ml}$ of blood or $0.5 \%, 128$ people living with HIV had a viral load between $1,500,000$ and 15,000 copies / $\mathrm{ml}$ of blood or $64 \%, 50$ patients had a viral load between 15,000 and 10,000 copies / $\mathrm{ml}$ of blood or $25 \%, 21$ patients had a viral load between 10,000 and 5,000 copies / ml of blood or $10.5 \%$ before therapeutic education. During our study, 149 people living with HIV or $74.5 \%$ were sad, 50 people or $25 \%$ frequently cried 1 patient or $0.5 \%$ remained indifferent. After therapeutic education, our entire study population $(100 \%)$ felt good. At the start of treatment, all 200 people living with HIV were taking the drugs morning and evening, $100 \%$. Currently our entire study population of $100 \%$ takes treatment at specific times.

\subsection{Data related to therapeutic education}

Table 6 Data related to therapeutic education February-August $2017(N=200)$

\begin{tabular}{|c|c|}
\hline Variables & Number $\%$ \\
\hline $\begin{array}{l}\text { FTE sessions } \\
\text { Individual } \ldots \ldots \ldots \ldots \ldots \ldots \ldots \ldots \ldots \ldots \\
\text { Groupe } \ldots \ldots \ldots \ldots \ldots \ldots \ldots \ldots \ldots \ldots \ldots \ldots \ldots \ldots\end{array}$ & $\begin{array}{l}200(100) \\
40(100)\end{array}$ \\
\hline $\begin{array}{l}\text { Educational diagnosis (cognitive dimension) } \\
\text { Knowledge of the disease before etp } \ldots \ldots \\
\text { Knowledge of the disease after etp } \ldots \ldots \\
\text { Non-compliance with the medication taking time before etp } \ldots \ldots \ldots \ldots \ldots \ldots \ldots \ldots \\
\text { Taking medication at specific times after etp }\end{array}$ & $\begin{array}{l}10(5) \\
200(100) \\
200(100) \\
200(100)\end{array}$ \\
\hline $\begin{array}{l}\text { Educational diagnosis (bio clinical dimension) } \\
\text { CD4 rate }<200 \mathrm{~mm} 3 \text { before etp } \ldots \ldots \ldots \\
\text { CD4 rate }>500 \mathrm{~mm} 3 \text { after etp } \ldots \ldots \ldots \\
\text { Viral load }>5000 \text { copies before etp } \ldots \ldots \ldots \\
\text { Viral load }<1000 \text { copies after etp } \ldots \ldots \ldots \\
\text { Poor adherence to treatment before etp } \ldots \ldots \ldots \ldots \ldots \ldots \ldots \ldots \ldots \ldots \\
\text { Good adherence to treatment after etp.... }\end{array}$ & $\begin{array}{l}200(100) \\
200(100) \\
200(100) \\
200(100) \\
200(100) \\
200(100)\end{array}$ \\
\hline $\begin{array}{l}\text { Educational diagnosis (socio-professional dimension) } \\
\text { Presence of activities before etp ........... }\end{array}$ & $20(10)$ \\
\hline
\end{tabular}




\begin{tabular}{|c|c|}
\hline $\begin{array}{l}\text { Presence of activities after etp } \ldots \ldots \ldots \ldots \ldots \\
\text { Persons informed before etp } \ldots \ldots \ldots \ldots \ldots \\
\text { People informed after etp } \ldots \ldots \ldots \ldots \ldots\end{array}$ & $\begin{array}{l}180(90) \\
110(55) \\
197(98,5)\end{array}$ \\
\hline $\begin{array}{l}\text { Educational diagnosis (psychoaffective dimension) } \\
\text { External aid } \ldots \ldots \ldots \ldots \ldots \ldots \ldots \ldots \ldots \ldots \ldots \ldots \\
\text { Affection of companions } \ldots \ldots \ldots \ldots \ldots \ldots \ldots \ldots \\
\text { Affection of children } \ldots \ldots \ldots \ldots \ldots \ldots \ldots \ldots\end{array}$ & $\begin{array}{l}110(55) \\
110(55) \\
197(98,5)\end{array}$ \\
\hline $\begin{array}{l}\text { Educational diagnosis (motivational dimension) } \\
\text { Existence of project before et............... } \\
\text { Existence of project after etp ................ }\end{array}$ & $\begin{array}{l}2(1) \\
198(99) \\
\end{array}$ \\
\hline $\begin{array}{l}\text { Influencing factors } \\
\text { Facilitating factors } \ldots \ldots \ldots \ldots \ldots \ldots \ldots \ldots \ldots \ldots \\
\text { Limiting factors } \ldots \ldots \ldots \ldots \ldots \ldots \ldots \ldots \ldots \ldots\end{array}$ & $\begin{array}{l}198(99) \\
2(1)\end{array}$ \\
\hline Educational contract & $200(100)$ \\
\hline $\begin{array}{l}\text { Self-care competence before etp }[\text { HIV contamination, drugs, viral load, side } \\
\text { effects }] \ldots \ldots \ldots \ldots \ldots \ldots \ldots \ldots \ldots \ldots \\
\text { Self-care competence after etp } \ldots \ldots \ldots \ldots \ldots\end{array}$ & $\begin{array}{l}198(99) \\
200(100)\end{array}$ \\
\hline $\begin{array}{l}\text { Adaptation skill after etp: } \\
\text { Specific needs, expectations } \ldots \ldots \ldots \ldots \ldots \ldots \ldots \\
\text { Acceptance of the disease } \ldots \ldots \ldots \ldots \ldots \ldots \ldots \ldots \\
\text { Contact with others } \ldots \ldots \ldots \ldots \ldots \ldots \ldots \ldots\end{array}$ & $\begin{array}{l}200(100) \\
200(100) \\
200(100)\end{array}$ \\
\hline $\begin{array}{l}\text { Self-efficacy } \\
\text { Know how to take charge, know how to mobilize your own resources } \ldots \ldots \ldots \ldots \ldots \ldots\end{array}$ & $200(100)$ \\
\hline 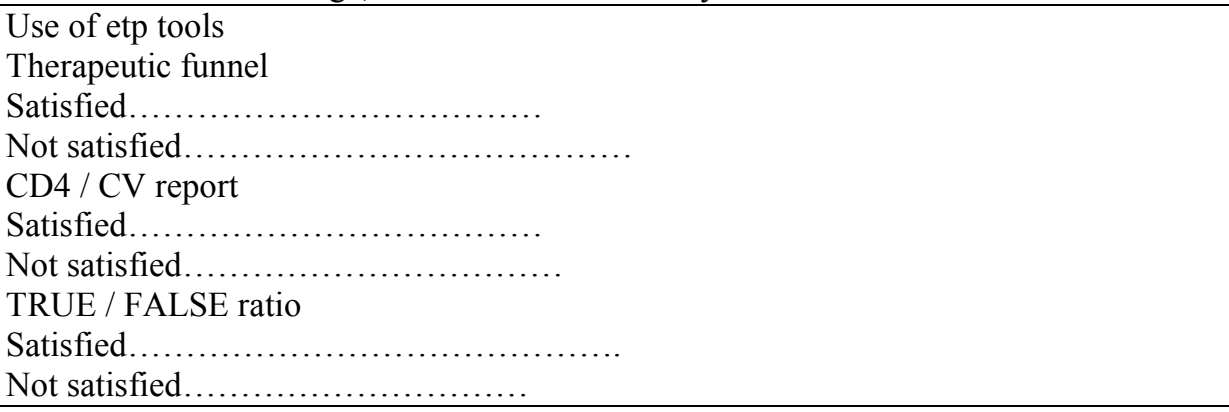 & $\begin{array}{l}200(100) \\
00(00) \\
180(90) \\
20(10) \\
10(5) \\
190(95) \\
\end{array}$ \\
\hline
\end{tabular}

The 200 people living with HIV who make up our study population participated in individual therapeutic education (100\%). Likewise, the 20 groups of 10 people participated in group therapeutic education activities. Before therapeutic education, 10 people or $5 \%$ had knowledge about HIV. (A. 2017)After the therapeutic education, all the patients learned about HIV. The drugs were taken at times (morning and evening) before the therapeutic education, after our passage all our study population takes their drugs at times taken. The cd4, which was less than $200 \mathrm{~mm} 3$ in all our patients, rose to more than $500 \mathrm{~mm} 3$ in all the patients. Just as the viral load which was very high at more than 5000 copies / $\mathrm{ml}$ of blood has dropped to less than 1000 copies / $\mathrm{ml}$ of blood after the therapeutic education. Also adherence to treatment, which was zero, became $100 \%$ good after FTE.

Before therapeutic education 20 people or 10\% thought of an activity; however, after 180 they are 180 or $90 \%$ having an activity. And 110 people or $55 \%$ of the patients had informed someone of their status, after the etp they are 197 or $98.5 \%$ to give the information. During this time 110 people or 55\% received help from outside and 110 patients or $55 \%$ had the affection of the companions; 197 people or $98.5 \%$ received affection from their children. Before FTE 198 patients or $99 \%$ had no project ideas; but after the fp they are 198 or $99 \%$ thinking about their project. During the sessions, 198 patients or $99 \%$ actively participated in the FTE; only 2 people or $1 \%$ was reserved. Before FTE 198 people living with HIV (98\%) had no knowledge of HIV, drugs, viral load and the side effects of drugs. (A. 2005)But after the FTE all the patients acquired a skill of self-care. Subsequently, their ability to adapt was reinforced with the self-efficacy of the acts. The use of the therapeutic funnel was $100 \%$ satisfied, the true / false ratio was $5 \%$, and the $\mathrm{cd} 4 / \mathrm{cv}$ ratio was $90 \%$ in the use of therapeutic education tools.

\section{DISCUSSION}

Making viral loads undetectable requires strategies that are not customary for managers of people living with HIV, so training is needed. (A.D. 2005)Thus, the introduction of therapeutic education in the care of people living with HIV with the effect of reducing the viral load constitutes a challenge. Our study places us in relation to the socioprofessional characteristics of people living with HIV. Indeed, to introduce therapeutic education in the care of people living with HIV, a certain amount of information must be available in the sense that people living with HIV 
must acquire skills that will enable them to achieve the objective which is the reduction of the viral load. Our study shows that the level of education of our patients is an obstacle to the implementation of certain therapeutic education tools. Indeed, $44.5 \%$ of our study population remains out of school, so the three FTE tools proposed for the demonstration gave different results; the therapeutic funnel was $100 \%$ appreciated. As for religion, $99.5 \%$ of our population belongs to a religion that allowed the intervention of men of God during the sessions of the ETP to support the spiritual aspect of the disease especially as some people think that this disease constitutes the price of sin especially when we know that in the world, the church has medical aid of nearly $25 \%$ in AIDS-related services and that in Africa this aid reaches on average 50\% (AFRAVIH 2015); (Cordaid Aids Award); (JDS / no 166 / special AIDS and spirituality / June 2004). The feminization of the HIV pandemic has been seen here too, indeed our study clarified that $71 \%$ of our population remains women than $29 \%$ are men (AMANI K.S.A 2000). The cd4 level was low before our study and the viral load in our patients is very high even six months after taking ARVs. (C. 2007)However, three months after therapeutic education, the cd4 level rose to more than $500 \mathrm{~mm} 3$ and the viral load dropped to less than 1000 copies / $\mathrm{ml}$ of blood. Our interest in educational diagnosis, especially for the cognitive dimension, clarified that patients had very little knowledge of HIV and that they had less information on ARV drugs; which causes difficulty in compliance. As for the psycho-emotional dimension: helpers, whether external, relatives or children, have been a source of motivation for people living with HIV to observe treatment. Nevertheless, certain factors were limiting when others facilitated the reduction of the viral load in our patients and allowed the realization of the educational contract to then reinforce the competence of self-care, the competence of adaptation and self -effectiveness of our patients. The methodology of therapeutic education used in our study was the same as that practiced elsewhere in the management of chronic diseases (cancer, diabetes, high blood pressure). Therapeutic education and adherence to HIV treatment by Martine Schlossers, ETP nurse, AP-HM is a very good demonstration of this. From our discussion we understand that FTE improves the quality of life of the patient, guaranteed therapeutic success since it is gradually integrated in Africa in hospitals in addition to medical care (E. 2010). It is true that the acquisition of educational skills and the implementation of the educational contract promote compliance, which is the catalyst for reducing the viral load, but also the good mental health of people living with HIV at an influence on good adherence to ARV treatments (P. 2013) .

\section{CONCLUSION}

UNAIDS 'global strategy to eradicate HIV by 2030 through its goals; zero new infections, zero discrimination and zero AIDS-related deaths (ONUSUDA 2015) guides our research in the sense that reducing the viral load in people living with HIV includes the component HIV prevention. This study has enabled us to note that socio-professional factors and HIV-related data are important elements to take into account in the care of people living with HIV. And to do this, therapeutic education, which is an educational science that enables patients to integrate the disease into their lives, deserves its place alongside medical care. Indeed, through the educational diagnosis with its cognitive dimension, (Nations Unies 2004)its bio clinical dimension, its psych affective dimension and the motivational dimension, the patient understands better what it is that HIV, AIDS and consequently accepts an educational contract guarantee of good adherence to treatment giving an undetectable viral load. However, our study has shown that although therapeutic education promotes reduction of viral load in people living with HIV, some people living with HIV despite not having attended therapeutic education had their viral load significantly reduced even if it is not suppressed. (J.F. 2008) It is in this sense that other studies should be considered to understand what are the other mechanisms that allow the reduction of viral load in people living with HIV especially that the national strategy of fight against HIV / AIDS Cote d'Ivoire is the "Test and Treat All" approach. In addition, another study to monitor and evaluate therapeutic education activities after reducing the viral load in people living with HIV may be needed.

\section{REFERENCES}

2016. "Guide National De L’éducation Thérapeutique Pour Adulte, Enfant Et Adolescent Vivant Avec Le Vih, Togo."

A., Abalo. 2017. " L’éducation Thérapeutique Du Patient (Etp) Pour Une Meilleure Prise En Charge Des Pvvih, Sida Information Vih-Sida. ."

A., Pellecchia. 2005. "Les Potentialités De L’art Dans L’éducation Thérapeutique Du Patient." université paris.

A.D., BLIBOLO. 2005. " Le Sida En Afrique : Réponse Des Praticiens De La Médecine Africaine En Matière De Prise En Charge Thérapeutique Et Psychosociale En Côte D’ivoire, Nyansa-Po." (3):75-92.

AFRAVIH. 2015. "Observance Thérapeutique Chez Les Adolescents De 15 À 19 Ans Infectés Par Le Vih Sous Trithérapie Antirétrovirale En Afrique Sub-Saharienne, Cote D'ivoire.".

AMANI K.S.A. 2000. "Itinéraires Thérapeutiques Des Patients Consultant En Hygiène Mentale, Thèse De Doctorat En Médecine Université De Cocody, Abidjan, ."(63-80) p.

Assata Pare Kabore, Rasmata Nabaloum-Bakayoko. 2014. Perspectives Africaines De L'education Des Adultes Socio-Psychologie L'education Des Adultes En Afrique 
C., Mouala. "Soins Palliatifs Et Qualité De Vie Des Patients Hiv, Transcriptases, (129).".

C., Tourette-Turgis. 2007. "La Consultation D'aide À L'observance Des Traitements De L'infection À Vih : L'approche Mothiv : Accompagnement Et Éducation Thérapeutique ".

d'Haïti, Gouvernement de la république. " 2008-2012. Programme National De Lutte Contre Le Sida. Plan Stratégique National Multisectoriel.".

E., DESMOTS. 2010. "Éducation Thérapeutique Chez Les Patients Vih Au Chu De Nancy: Bilan Du Programme Mis En Place En 2008, Mémoire Du Diplôme D'études Spécialisées De Pharmacie Hospitalières Et Collectivités.".

Gandonou, Fifame Fidele Houssou. 2016. Les Fondements Ethiques Du Feminisme Reflexions a Partirs Du Contexte Africain Edited by G. n. t. 22.

HAS. 2014. "Education Thérapeutique Du Patient : Indicateurs Dans Le Champ De L'éducation Thérapeutique Du Patient."

HIV/AIDS, Canadian. "Réseau Juridique Canadian Hiv/Sida, Vaccins Anti-Vih/Sida : Notions De Base, Trousse D'action Communautaire Vaccins Anti-Vih Et Droits Humains.".

J.F., D’Ivernois. 2008. "Quelle Éducation Thérapeutique Du Patient ?, Université Paris Xiii, Journée Médicale De La Msa."

Mutondon, Kitoka Moke. 2012. Eglise,Protection Des Droits De L'ommes Et Refondation De L'etat Republique Democratique Du Congo, Essai D'une Ethique Politique Engagee, Edited by G. n. theses.

Nations Unies, Conseil Economique et Social 2004. La Dimension Féminine Du Vih/Sida En Afrique, Septième Conférence Régionale Africaine Sur Les Femmes Examen Décennal De La Mise En Euvre De La Plateforme D'action De Dakar Et Du Programme D'action De Beijing Addis-Abeba, Ethiopie.

Ogalama, Yabo Gabriel. 2013. "La Pratique De L'urbanisation En Afrique Subsaharienne , Bilan Et Perspective Strategique , L'exemple De La Villede Bangui ( Centrafique )." Universite Francois - Rabelais de tours

ONEC. 2013. "Outil National D'évaluation Des Capacités Techniques Et Organisationnelles Des Ong ".

ONUSIDA , UNESCO. 2002. L'approche Culturelle De La Prevention Et Du Traitement Du Vih/Sida, Manuels Methodologiques.

ONUSUDA. 2015. "Onusida/2011-2015. Stratégie, Objectif : Zéro.".

P., Gantner. 2013. "Éducation Thérapeutique Des Patients Vivant Avec Le Vih, Le Trait D’union, Centre De Soins De L'infection Par Le Vih.".

Pohor Rubin, Njegollmi Mbairodibbeee. Mission Integrale, Manuel De Formation Cahier Iii.

program, UNAIDS. 2016. " Access to Dugs, Unaids Technical Update. In: Unaids Best Practice Collection, Unaids Éd. Geneva, October 1998, 2016.".

sida, Institut National de la statistique (INS) et ministère de la lutte contre le. 2005. "Cote D'ivoire Et Measure Ohs, Orc Macro, Enquête Sur Les Indicateurs Du Sida En Côte D'ivoire."

T.K, Coumba. 2009. "De La Résistance Aux Arv En Afrique : Cas Du Sénégal, 3e Journées Scientifique Vih/Sida, Niamey Niger.".

Tiembré I., Ekra D., Bénié J. et al. 2009. "Séroprévalence De L'infection À Vih/Sida Dans Un Centre De Conseil De Dépistage Périphérique D'abidjan, Cote D'ivoire." Médecine Afrique noire.

UNESCO. 2006. "Guide De Formation Des Facilitateurs En Alphabétisation Et En Éducation Non Formelle En Afrique.".

UNICEF, Fonds des Nations Unies pour l'enfance. 2010. " Enfant Et Sida,. Cinquième Bilan De La Situation." WWW.UNAC.org. 2002. "Les Jeunes Et La Crise Mondiale Du Vih/Sida: Des Outils Pour Passer a L'action ". 